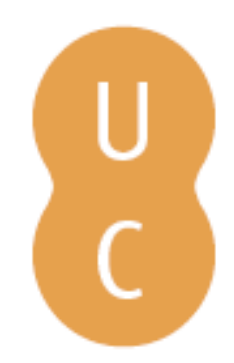

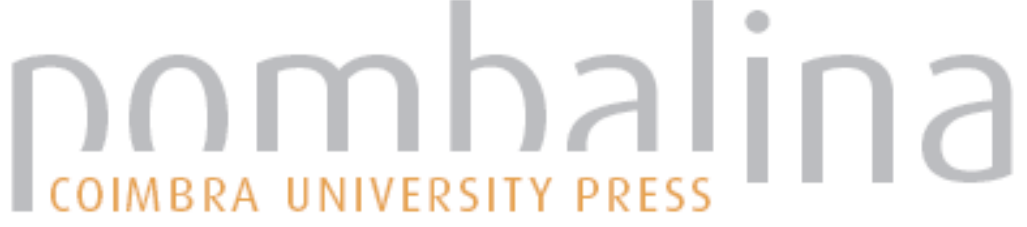

\section{Developmental change of orientations to self-change during adolescence}

\author{
Autor(es): $\quad$ Yuta, Chishima
}

Publicado por: Imprensa da Universidade de Coimbra

URL

persistente: URI:http://hdl.handle.net/10316.2/38606

DOI: $\quad$ DOI:http://dx.doi.org/10.14195/978-989-26-0775-7_2

Accessed : $\quad$ 26-Apr-2023 16:07:02

A navegação consulta e descarregamento dos títulos inseridos nas Bibliotecas Digitais UC Digitalis, UC Pombalina e UC Impactum, pressupõem a aceitação plena e sem reservas dos Termos e Condições de Uso destas Bibliotecas Digitais, disponíveis em https://digitalis.uc.pt/pt-pt/termos.

Conforme exposto nos referidos Termos e Condições de Uso, o descarregamento de títulos de acesso restrito requer uma licença válida de autorização devendo o utilizador aceder ao(s) documento(s) a partir de um endereço de IP da instituição detentora da supramencionada licença.

Ao utilizador é apenas permitido o descarregamento para uso pessoal, pelo que o emprego do(s) título(s) descarregado(s) para outro fim, designadamente comercial, carece de autorização do respetivo autor ou editor da obra.

Na medida em que todas as obras da UC Digitalis se encontram protegidas pelo Código do Direito de Autor e Direitos Conexos e demais legislação aplicável, toda a cópia, parcial ou total, deste documento, nos casos em que é legalmente admitida, deverá conter ou fazer-se acompanhar por este aviso. 


\section{INTERNATIONAL \\ STUDIES IN TIME \\ PERSPECTIVE}

MARIA PAULA PAIXÃO

JOSÉ TOMÁS DA SILVA

(COORD.)

VICTOR ORTUÑO

PEDRO CORDEIRO

(EDITORS)

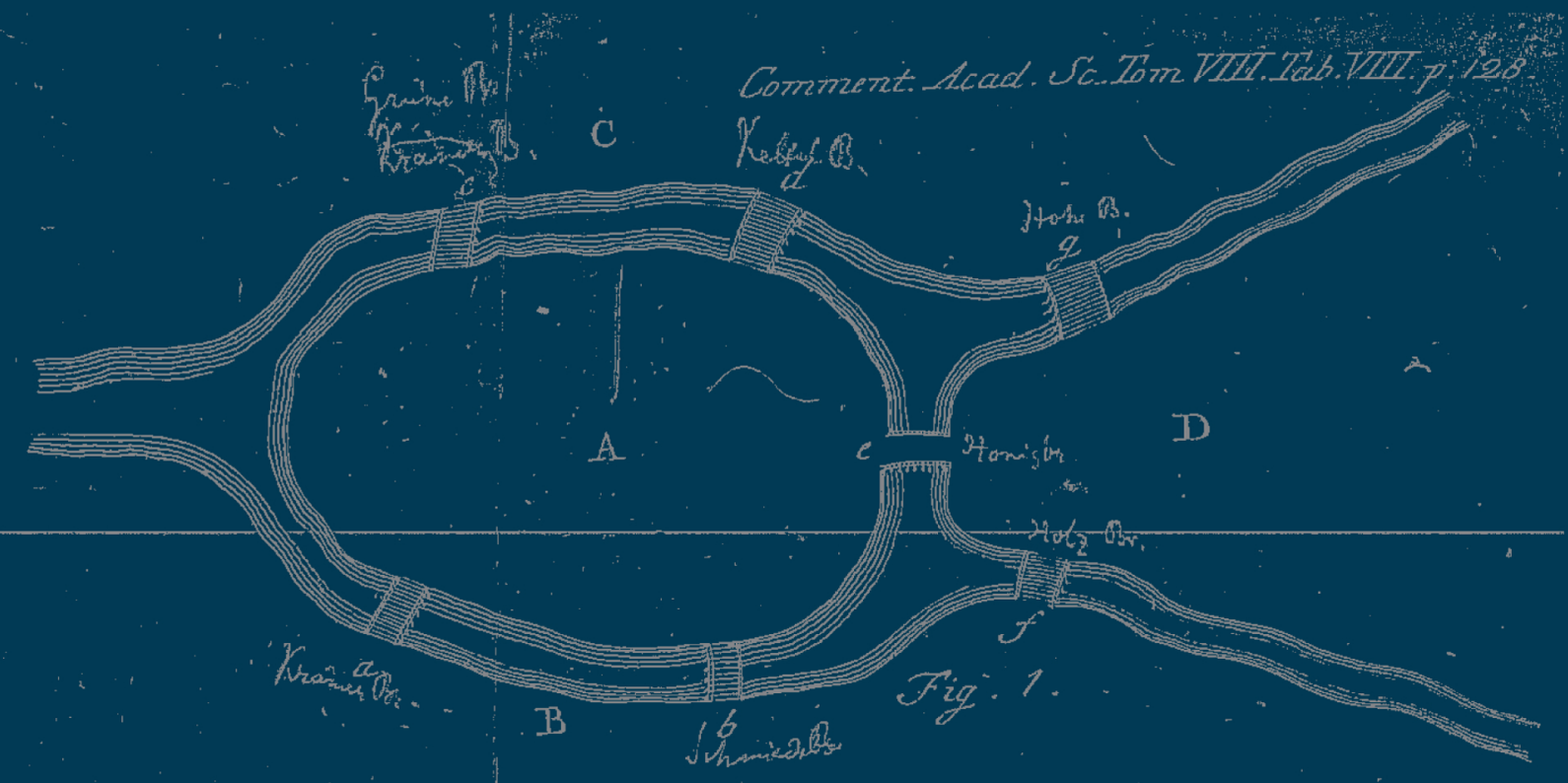

IMPRENSA DA

UNIVERSIDADE

DE COIMBRA

COIMBRA

UNIVERSITY

PRESS 


\title{
Chapter 2 \\ DeVELOPMENTAL CHANGE OF ORIENTATIONS TO SELF-CHANGE DURING ADOLESCENCE
}

\author{
Chishima Yuta \\ Graduate school of comprehensive human sciences, University of Tsukuba, Japan \\ chishima@human.tsukuba.ac.jp
}

\begin{abstract}
Aвstract: The purpose of this study was to examine developmental changes in orientations to self-change in adolescence, focusing on early, middle, and late adolescents. Although it is well known that many adolescents want to change themselves, few studies have examined how orientations to self-change evolve during adolescence. A total of 1,128 Japanese adolescents aged 13 to 25 (353 junior high school students, 375 high school students, and 400 university students) responded to an orientations to self-change scale consisting of 40 items. Results of a factor analysis indicated that the orientations to self-change consisted of 10 factors. A principal component analysis of the 10 factors resulted in a distribution along two axes: Future Selves--Past Selves and Positive Others--Negative Selves. Results of ANOVA comparing 10 scores with 3 school stages indicated that the orientations to self-change could evolve through three stages in adolescence. At first, adolescents want to change all of themselves, then they tend to refer to their past selves and current others in changing themselves as they grow, and finally they reach the stage of referring to future selves, so that they want to improve specific aspects of themselves.
\end{abstract}

Keywords: developmental change, orientations to self-change, self, adolescence.

\section{INTRODUCTION}

Many people are eager to rebuild themselves, especially in adolescence (Hatase, 2000; Mizuma, 2003). Heretofore, concepts relating to intentional self-change that have been examined, for example, "self-improvement motivation" (Taylor, Neter, \& Wayment, 1995) and "possible selves" (Markus \& Nurius, 1986). Chishima (2012) suggested the concept of Orientations to Self-Change (OSC) to organize concepts related to intentional self-change. Then, how do OSC develop during adolescence? Boyatzis (2006) proposed Intentional Change Theory, which describes the process from finding the ideal self to the achievement of self-change. Kiecolt (1994) also developed a model in which the impetus for intentional self-change could be provided by a stressor-chronic role strain, a life event, or both. However most of these studies have focused on addictive behaviors and haven't taken into account adolescent development. 


\section{Method}

\section{Participants}

Participants were 1,128 adolescents aged from 13 to 25 years, including 353 junior high school students as early adolescents, 375 high school students as middle adolescents, and 400 university students as late adolescents (Table 1).

Table 1 - Characteristics of participants

\begin{tabular}{ccccc}
\hline & $\begin{array}{c}\text { Early } \\
\text { Adolescents }\end{array}$ & $\begin{array}{c}\text { Middle } \\
\text { Adolescents }\end{array}$ & $\begin{array}{c}\text { Late } \\
\text { Adolescents }\end{array}$ & Total \\
\hline Men & 178 & 185 & 156 & 519 \\
Women & 174 & 187 & 242 & 603 \\
Gender non-respondents & 1 & 3 & 2 & 6 \\
Total & 353 & 375 & 400 & 1128 \\
\hline Mean age & 13.47 & 15.92 & 20.35 & 16.72 \\
(SD) & $(1.19)$ & $(1.35)$ & $(2.12)$ & $(3.29)$ \\
\hline
\end{tabular}

\section{Measures}

The orientations to self-change scale by Chishima (2012) was used. Participants were asked "To what extent do the following items apply to you?" Each item used a five point Likert-type scale ranging from "does not apply at all" (1) to "applies exactly" (5), with higher scores reflecting stronger orientations toward self-change.

\section{Procedures}

The research was conducted from September to October in 2011. The questionnaires were distributed to the participants and picked up during classroom time.

\section{RESULTS}

Results of a factor analysis with only the university students' data indicated that the orientations to self-change items contained 10 factors. These factors were named based on the items with high factor loadings. The mean of the scores on the OSC were calculated for items with over .40 factor loadings. Then, using the same items as for the university students, the scores for the junior high and high school students were calculated. Table 2 shows the statistics and example items of the OSC.

Next, a principal component plot of the OSC scores was made to understand the characteristics of the 10 scores in detail. In Figure 1, on the horizontal axis, the F1 Nostalgia score was highest, and the F10 Improvement score was lowest, whereas on the vertical axis, the F3 Adoration was highest, and the F7 Renewal was lowest. Therefore the horizontal axis was interpreted as the Future Selves - Past Selves axis. The vertical axis was interpreted as the Positive Others - Negative Selves axis. 
Table 2 - Statistics and example items in 10 orientations to self-change

\begin{tabular}{ccccl}
\hline Factor names & $\begin{array}{c}\text { Mean } \\
(1 \text { to 5) }\end{array}$ & (SD) & $\alpha$ & Example items \\
\hline F1 Nostalgia orientation & 2.24 & $(0.91)$ & .89 & I want to get back my former self. \\
F2 Foresight orientation & 3.76 & $(0.88)$ & .84 & When I think of my future, I don't want to continue being what I am today. \\
F3 Adoration orientation & 3.47 & $(0.94)$ & .83 & I want to change mys elf to be like others whom I adore. \\
F4 Change-seeking orientation & 2.90 & $(0.91)$ & .83 & I constantly want to change. \\
F5 Personableness orientation & 3.64 & $(0.95)$ & .87 & I want to change to get applause from others. \\
F6 Rebirth orientation & 2.65 & $(1.07)$ & .88 & I want to make over all of me. \\
F7 Renewal orientation & 3.30 & $(0.95)$ & .83 & I want to renew myself because I am not making any progress. \\
F8 Imitation orientation & 2.34 & $(0.83)$ & .77 & I want to change myself by imitating people I'm familiar with. \\
F9 Discovery orientation & 3.15 & $(1.00)$ & .81 & I want to change myself to find my true self. \\
F10 Improvement orientation & 4.28 & $(0.69)$ & .72 & I want change my bad points. \\
\hline
\end{tabular}

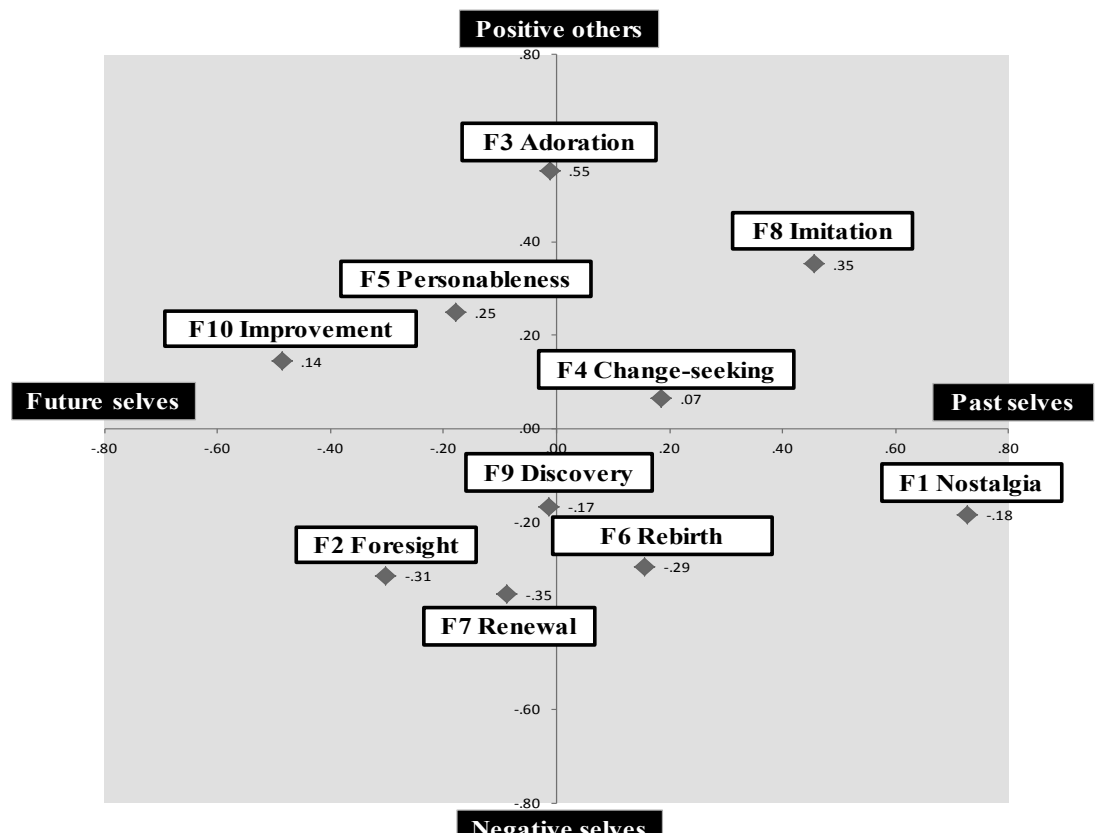

Negative selves

Figure 1. Principal component plot of scores in 10 orientations to self change.

Note. Second component loadings were plotted on the horizontal axis and third component loadings were plotted on the vertical axis.

An analysis of variance was conducted to compare the 10 OSC scores with each school stage (Table 3). The results of multiple comparisons using Tukey's HSD test $(p<.05)$ indicated that the F6 Rebirth scores for the junior high and high school students were higher than for the university students. The F1 Nostalgia scores and the F5 Personableness scores for high school students were higher than for junior high school and university students. The F7 Renewal scores for high school students were higher than for junior high school students. The F2 Foresight scores and the F10 Improvement scores for high school students and university students were higher than for junior high school students. The F4 Change-seeking scores increased as students got older. 
Table 3 - ANOVA results of OSC scores of between three school stages

\begin{tabular}{|c|c|c|c|c|c|c|}
\hline & \multirow{2}{*}{$\begin{array}{c}\begin{array}{c}\text { Early } \\
\text { Adolescents }\end{array} \\
n=353\end{array}$} & $\begin{array}{c}\text { Middle } \\
\text { Adolescents }\end{array}$ & $\begin{array}{c}\text { Late } \\
\text { Adolescents } \\
\end{array}$ & \multicolumn{2}{|c|}{$F$ Value } & \multirow[t]{2}{*}{$\begin{array}{c}\text { Multiple } \\
\text { comparison }\end{array}$} \\
\hline & & $n=375$ & $n=400$ & & & \\
\hline \multirow{2}{*}{ F6 Rebirth } & 2.67 & 2.81 & 2.48 & \multirow{2}{*}{9.32} & \multirow{2}{*}{$* * *$} & \multirow{2}{*}{$\mathrm{L}<\mathrm{E}, \mathrm{M}$} \\
\hline & (1.08) & (1.08) & $(1.02)$ & & & \\
\hline \multirow{2}{*}{ F1 Nostalgia } & 2.19 & 2.41 & 2.13 & \multirow{2}{*}{10.13} & \multirow{2}{*}{$* * *$} & \multirow{2}{*}{$\mathrm{E}, \mathrm{L}<\mathrm{M}$} \\
\hline & $(0.83)$ & $(0.99)$ & $(0.89)$ & & & \\
\hline \multirow{2}{*}{ F5 Personableness } & 3.57 & 3.76 & 3.59 & \multirow{2}{*}{4.50} & \multirow{2}{*}{ * } & \multirow{2}{*}{$\mathrm{E}, \mathrm{L}<\mathrm{M}$} \\
\hline & $(0.96)$ & $(0.92)$ & $(0.94)$ & & & \\
\hline \multirow{2}{*}{ F7 Renewal } & 3.18 & 3.41 & 3.31 & \multirow{2}{*}{5.69} & \multirow{2}{*}{$* *$} & \multirow{2}{*}{$\mathrm{E}<\mathrm{M}$} \\
\hline & $(0.92)$ & $(0.91)$ & $(0.99)$ & & & \\
\hline \multirow{2}{*}{ F2 Foresight } & 3.59 & 3.77 & 3.89 & \multirow{2}{*}{10.97} & \multirow{2}{*}{$* * *$} & \multirow{2}{*}{$\mathrm{E}<\mathrm{M}, \mathrm{L}$} \\
\hline & $(0.94)$ & $(0.88)$ & $(0.81)$ & & & \\
\hline \multirow{2}{*}{ F10 Improvement } & 4.08 & 4.36 & 4.38 & \multirow{2}{*}{21.58} & \multirow{2}{*}{$* * *$} & \multirow{2}{*}{$\mathrm{E}<\mathrm{M}, \mathrm{L}$} \\
\hline & $(0.77)$ & $(0.64)$ & $(0.62)$ & & & \\
\hline \multirow{2}{*}{ F4 Change-s eeking } & 2.62 & 2.93 & 3.11 & \multirow{2}{*}{28.94} & \multirow{2}{*}{$* * *$} & \multirow{2}{*}{$\mathrm{E}<\mathrm{M}<\mathrm{L}$} \\
\hline & $(0.86)$ & $(0.89)$ & & & & \\
\hline
\end{tabular}

Note 1 . The significantly higher scores were shaded.

Note 2. The scores of OSC were reordered based on results of multiple comparison.

Note 3. E:Early Adolescents; M:Middle Adolescents; L: Late Adolescents.

Note $4 .{ }^{*} p<.05,{ }^{* *} p<.01,{ }^{* * *} p<.001$

\section{Discussion}

The results of a comparison of OSC scores among three school stages suggest that orientations to self-change evolve through the three stages.

First, for early adolescents, is the stage of self-change orientation referring to the whole selves. This stage shows higher the F6 Rebirth scores in junior high and high school students. Early adolescents haven't yet developed cognitive skills for objectivizing themselves or imaging the future. Therefore they want to change all of themselves. The second stage, regarding middle adolescence, is the stage referring to past selves/positive others. This stage shows the F1 Nostalgia scores, the F7 Renewal scores, and the F5 Personableness scores higher in junior high school students. Middle adolescents tend to show a past orientation, and be nervous about gaining esteem from others. Therefore they tend to want to change themselves to be the former selves and to get the approval of current others. Third is the stage referring to future selves. This stage shows the F2 Foresight scores, the F4 Change-seeking scores, and the F10 Improvement scores higher in high school and university students. Late adolescents are motivated to improve their bad points for the future.

In the light of the above findings, developmental change in the orientations to selfchange during adolescence could be summarized as follows. At first, adolescents want to change all of themselves, then they tend to refer to their past selves and current others in changing themselves as they grow, and finally they reach the stage of referring to future selves, so that they want to improve specific aspects of themselves. 
For future research, the extent to which they actualize self-change (cf. Polivy \& Herman, 2002) needs to be examined.

\section{REFERENCES}

Boyatzis, R. E. (2006). An overview of intentional change from a complexity perspective. Journal of Management Development, 25, 607-623.

Chishima, Y. (2012). Orientations to self-change in adolescence: Focusing on the relations with identity statuses. The Asian Conference on Psychology \& the Behavioral Sciences (Abstract).

Hatase, N. (2000). University students' counseling services: Filling the gap of desire to rebuild oneselves. Japanese Journal of Adolescent Psychology, 12, 1-14.

Kiecolt, K. J. (1994). Stress and the decision to change oneself: A theoretical model. Social Psychology Quarterly, 57, 49-63.

Markus, H., \& Nurius, P. (1986). Possible selves. American Psychologist, 41, 954-969.

Mizuma, R. (2003). Feelings of self-disgust and self-development: the intention to change the negative self. Japanese Journal of Educational Psychology, 51, 43-53.

Polivy, J., \& Herman, C. P. (2002). If at first you don't succeed: False hopes of self-change. American Psychologist, 57, 677-689.

Taylor, S. E., Neter, E., \& Wayment, H. A. (1995). Self-evaluation processes. Personality and Social Psychology Bulletin, 21, 1278-1287. 